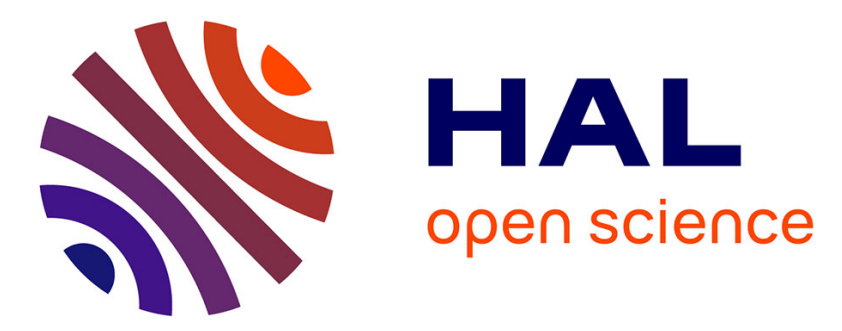

\title{
Effects of vascular endothelial growth factor on isolated fetal alveolar type II cells
}

\author{
William Raoul, Bernadette Chailley-Heu, Anne-Marie Barlier-Mur, \\ Christophe Delacourt, Bernard Maitre, Jacques R. Bourbon
}

\section{To cite this version:}

William Raoul, Bernadette Chailley-Heu, Anne-Marie Barlier-Mur, Christophe Delacourt, Bernard Maitre, et al.. Effects of vascular endothelial growth factor on isolated fetal alveolar type II cells. American Journal of Physiology - Lung Cellular and Molecular Physiology, 2004, 286 (6), pp.L1293 L1301. 10.1152/ajplung.00157.2003 . inserm-01755344

\section{HAL Id: inserm-01755344 https://www.hal.inserm.fr/inserm-01755344}

Submitted on 30 Mar 2018

HAL is a multi-disciplinary open access archive for the deposit and dissemination of scientific research documents, whether they are published or not. The documents may come from teaching and research institutions in France or abroad, or from public or private research centers.
L'archive ouverte pluridisciplinaire HAL, est destinée au dépôt et à la diffusion de documents scientifiques de niveau recherche, publiés ou non, émanant des établissements d'enseignement et de recherche français ou étrangers, des laboratoires publics ou privés. 
LCMP-00157-2003.R1 (revised)

Effects of vascular endothelial growth factor (VEGF) on isolated fetal alveolar type II cells.

WILLIAM RAOUL, BERNADETTE CHAILLEY-HEU, ANNE-MARIE BARLIER-MUR, CHRISTOPHE DELACOURT, BERNARD MAÎTRE, AND JACQUES R. BOURBON

Inserm U492, Faculté de Médecine, Université Paris XII, 94010 Créteil, France

Running title : Effects of VEGF on fetal type II cells 


\begin{abstract}
Previous investigations gained from in vivo or lung explant studies suggested that VEGF is an autocrine proliferation and maturation factor for developing alveolar type II cells. The objective of this work was to determine whether VEGF exerted its growth and maturation effects directly on isolated type II cells. These were isolated from $19 \mathrm{~d}$-fetal rat lung and cultured in defined medium. The presence of VEGF receptor VEGFR2 was assessed in cultured cells at the pre- and post-translational levels. Recombinant VEGF 165 formerly found to be active on lung explants failed to enhance type II cell proliferation estimated by thymidine and BrdU incorporation. It increased choline incorporation in saturated phosphatidylcholine by $27 \%$, but did not increase phospholipid surfactant pool size. VEGF $100 \mathrm{ng} / \mathrm{ml}$ let unchanged the transcript level of surfactant proteins SP-A, SP-C, and SP-D, but increased SP-B transcripts to 4 times the control steady-state level. VEGF slightly retarded, but did not prevent the in vitro transdifferentiation of type II into type I cells as assessed by immunolabeling of the type I cell marker T1 $\alpha$. We conclude that with the exception of SP-B expression that appears to be controlled directly, the previously observed effects of this VEGF isoform upon type II cells are likely to be exerted indirectly through reciprocal paracrine interactions involving other lung cell types.
\end{abstract}


VASCULAR ENDOTHELIAL GROWTH FACTOR (VEGF, also designated VEGF-A) is considered to play multiple crucial roles in lung development. Disruption of the VEGF-VEGF receptor signaling in the developing rat with aid of the receptor inhibitor Su-5416 not only reduced pulmonary arterial density, but also led to impaired alveolarization, emphysema, and pulmonary hypertension $(20,21,23)$. The VEGF null mutation is lethal early in development even in the heterozygous status (13), but it is possible to obtain development of mice expressing only one of the VEGF isoforms. Mice deleted for the predominant isoforms in the lung exhibited abnormal lung vascular development (25) and respiratory distress at birth (8). The importance of VEGF for normal lung development is also highlighted by the fact that infants dying from bronchopulmonary dysplasia had reduced pulmonary levels of VEGF (4). In the lung, alveolar type II cells are the major source of VEGF $(1,19,25,33)$, the epithelial cells that secrete surfactant and maintain alveolar epithelial renewal (11). VEGF production by type II cells is up regulated by hypoxia (27). The vascular endothelial growth factor receptor 2 (VEGFR2/Flk1/KDR) is expressed early in the lung bud mesenchyme, then in its vascular derivatives $(4,18)$; its expression and that of VEGF show coordinate increase during the course of pre- and postnatal lung development (4). It has been suggested recently, however, that alveolar type II cells may themselves represent targets for VEGF. Thus, human recombinant VEGF was reported to induce type II cell proliferation and to stimulate the expression of surfactant proteins SP-A and SP-C in cultured fetal human lung explants (5). Moreover, mice deficient for the hypoxia-inducible transcription factor HIF-2 $\alpha$ displayed severe respiratory distress at birth due to impaired thinning of alveolar sac septa and defective surfactant production (8). Importantly, this was overcome by in utero treatment by VEGF (8). These investigations indicate an involvement of VEGF in the control of alveolar maturation, but raise the question of VEGF effects on type II cells being exerted either directly or indirectly through the release of other mediator(s) from other lung cell type(s). The observations that type II cells express VEGFR2 (5) and that recombinant VEGF enhanced SP-B and SP-C expression in isolated adult rat lung type II cells as assessed by semi- 
quantitative RT-PCR (8) argued in favor of direct effect. To further analyze the role of VEGF in growth and maturation of the developing lung alveolar epithelial cells, we isolated the latter from the lung of the rat fetus, and we tested the effects of exogenous VEGF on type II cell proliferation and maturation, including production of surfactant phospholipids and proteins. Since VEGF was reported in a transgenic model of overexpression to inhibit type I cell differentiation (37), we also determined whether VEGF influenced the in vitro type II cell to type I cell conversion.

\section{MATERIALS AND METHODS}

Type II cell isolation and primary culture. Dated pregnant Sprague-Dawley rats were purchased from Charles River (Saint-Germain sur l'Arbresle, France). Term is 22 days. On gestational day 20 , fetuses were removed through cesarean section under pentobarbital anesthesia of the pregnant rats, and their lungs were collected aseptically. Fetal lung cells were enzymatically dispersed and type II cells were isolated as described previously through serial differential adhesions to plastic and low speed centrifugations $(7,16)$. Immunolabeling for cytokeratin and vimentin has shown epithelial cells obtained through this procedure to be over $95 \%$ pure (16). Purified type II cells were seeded directly on plastic for proliferation studies (14) and for transdifferentiation into type I cells (9), or after coating with EngelbrethHolm-Swarm (EHS) basement membrane matrix to maintain type II cell phenotype $(7,9)$ in surfactant studies. Cells were allowed to adhere overnight to the substratum under air- $\mathrm{CO}_{2}$ (95\%-5\%,v:v) at $37^{\circ} \mathrm{C}$ in MEM containing $10 \%$ FBS. The following morning, FBS-containing medium was removed, cells were rinsed twice with MEM, and a defined culture medium based on D-MEM enriched with various additives including penicillin, streptomycin, bovine transferrin, biotin, sodium selenite, and metal trace elements was introduced $(7,16)$. Cells were incubated for an additional $48 \mathrm{~h}$ or $72 \mathrm{~h}$ under the same conditions; fresh medium was introduced at time $48 \mathrm{~h}$ for $72 \mathrm{~h}$-cultures. Fetal type II cells grown on EHS matrix in this 
medium have been shown to mature in vitro with accumulation of the various surfactant components $(15,16)$ and to respond to exogenous growth factors $(7)$. Media, serum and antibiotics were from Invitrogen (Cergy-Pontoise, France); additives were from Invitrogen or Sigma (L'Isle d'Abeau, France) and were cell-culture tested. Recombinant human (rh) VEGF $_{165}$ (R\&D Systems Europe, Abingdon, UK) and recombinant human keratinocyte growth factor (KGF, R\&D Systems Europe) were added to defined culture medium at concentrations specified in Results.

VEGFR2, CD31, SP-A, SP-B, and T1 $\alpha$ Immunolabeling. Cells grown on EHS matrix were harvested with aid of Matrisperse (Collaborative Biomedical Products, Bedford, MA) and pelleted. The pellet was immediately frozen on the top of a Tissue-Tek (Sakura-Europe, Zoeterwoude, The Netherlands) support. Five $\mu \mathrm{m}$ sections were cut with aid of a Leica "Jung CM3000“ cryostat, and fixed in methanol for $5 \mathrm{~min}$ at $-20^{\circ} \mathrm{C}$. Cells grown on plastic for 48 and $72 \mathrm{~h}$ were directly fixed in cold methanol. Sections and cells were rinsed with phosphatebuffered saline (PBS). For peroxidase-based antibody detection, endogenous peroxidase was blocked by incubation in 3\% hydrogen peroxide in PBS, before incubation in PBS / $1 \%$ bovine serum albumin (PBS/BSA, Sigma) for 30min to block nonspecific binding sites. After washing, sections were incubated for $1 \mathrm{~h}$ with primary antibody, which included a monoclonal antibody against the carboxy terminus of VEGFR2/Flk-1 (Santa Cruz Biotechnology, Santa Cruz, CA), and a mouse anti-rat CD31 (platelet/endothelial cell adhesion molecule-1, PECAM-1) monoclonal antibody (BD Biosciences Pharmingen), both diluted 1:50. Sections were washed in PBS-tween $0.05 \%$, and incubated successively with goat anti-mouse biotinylated secondary antibody (Sigma), with extravidin-peroxidase reagent (Sigma) for 30min, and with diaminobenzidine (DAB, Vector Laboratories) for $5 \mathrm{~min}$, then counterstained with hematoxylin for 30s. Negative controls were (i) sections incubated with rhVEGF (R\&D Systems Europe) to saturate cell receptors before antibody incubation (final concentration: $300 \mathrm{ng} / \mathrm{ml}$ ), and (ii) sections incubated without primary antibody. Sections were viewed with Charge-Coupled Device Iris camera (CCD Iris, Sony, France) coupled with an optical 
microscope (Laborlux, Germany), and images were obtained with Perfect Image software (ClaraVision, Orsay, France). For immunofluorescent localization, cells were exposed to the blocking solution PBS/BSA before incubation with the primary antibodies, which included the anti-VEGFR2 antibody, polyclonal rabbit anti-SP-A (gift from M. Post) or anti-SP-B (gift from J.A. Whitsett) antibodies, and a monoclonal antibody against rat alveolar epithelial type I cell surface marker T1 $\alpha$ (gift from M.C. Williams). After washing, either FITC-conjugated goat anti-rabbit, or rhodamine-conjugated goat anti-mouse lgG antibodies (all from Biomeda) were used. Double labeling was performed for co-localization of markers. Sections or cells were observed with aid of a Zeiss Axioskop-40 fluorescence microscope at the appropriate excitation and detection wavelengths. Images were electronically obtained with Kappa ImageBase software.

Western blot analysis. Cells grown on EHS matrix in the presence or absence of VEGF were lysed in $50 \mathrm{mM}$ Tris-HCl buffer, pH7.4, containing $150 \mathrm{mM} \mathrm{NaCl}, 2 \mathrm{mM}$ EDTA, 5mM dithiothreitol, $0.1 \mathrm{mM}$ phenylmethylsulfonyl fluoride, $1 \mathrm{mM}$ leupeptin, $0.3 \% \mathrm{NP} 40$, and $0.2 \%$ Triton X100. Lysates were suspended in reducing or non-reducing-Laemmli sample buffer, boiled for $5 \mathrm{~min}$ and separated by 6 or 12\% SDS-PAGE in Tris-glycine-SDS or Tris-tricineSDS running buffer. Proteins were transferred onto Immobilon membranes (Millipore, Bedford, MA), blocked with $10 \%$ nonfat milk, and probed with anti-VEGFR2/Flk1 antibody or rabbit polyclonal anti-SP-B antibody as specified above, and mouse monoclonal anti- $\beta$ actin antibody (Sigma). Blots were probed with a horseradish peroxidase-conjugated secondary antibody and detected using Enhanced Chemiluminescence Assay (PerkinElmer, Courtaboeuf, France).

$\left[{ }^{3} \mathrm{H}\right]$-Thymidine incorporation and BrdU labeling. [methyl- $\left.{ }^{3} \mathrm{H}\right]$-Thymidine $(1.89 \mathrm{TBq} / \mathrm{mmol}$, Amersham, Orsay, France) was added to defined medium at final volumic activity $7.4 \mathrm{kBq} / \mathrm{ml}$ $(0.2 \mu \mathrm{Ci} / \mathrm{ml})$. After $48 \mathrm{~h}$-incorporation by cells cultured on plastic in 24 -well culture plates, cells 
were rinsed twice with cold phosphate-buffered saline (PBS), DNA was precipitated with 5\% TCA, dissolved in $200 \mu$ l sodium hydroxide $1 \mathrm{~N}$ and neutralized by $200 \mu$ acetic acid $1 \mathrm{~N}(28)$. After scrapping with aid of a rubber policeman, $200 \mu$ l aliquots were used to determine incorporated radioactivity in OptiPhase "Hisafe" scintillation cocktail (Wallac Scintillation Products, PerkinElmer). 5-Bromo-2'-deoxy-uridine (BrdU) labeling kit was purchased from Roche Diagnostics (Mannheim, Germany) and used to label cells cultured on Sonic seal slide wells (Nunc, Naperville, IL); counterstaining of all cell nuclei with dye Hoechst 33258 (Sigma) allowed the proportion of labeled cells to be evaluated.

$\left[{ }^{3} \mathrm{H}\right]$-Choline incorporation into saturated phosphatidylcholine. For evaluating the rate of synthesis of the major surfactant component, saturated phosphatidylcholine (sat-PC), cells cultured on EHS matrix in 12-well culture plates were exposed to [methyl- ${ }^{3} \mathrm{H}$ ]-choline chloride (2.92TBq $/ \mathrm{mmol}$, Amersham) at a final concentration of $18.5 \mathrm{kBq} / \mathrm{ml}(0.5 \mu \mathrm{Ci} / \mathrm{ml})$. After $48 \mathrm{~h}$ incorporation, cells were rinsed twice with PBS and recovered with Matrisperse. Lipids were extracted in the presence of unlabeled lung tissue homogenate (carrier tissue) and of a trace amount of $\left[{ }^{14} \mathrm{C}\right]$-dipalmitoylphosphatidylcholine (42GiBq/mmol, Amersham) for determination of recovery, then sat-PC was separated by osmium-tetroxide treatment and thin-layer chromatography as described previously $(6,7)$. Incorporated activity was counted in OptiScint "Hisafe" scintillation cocktail (Wallac Scintillation Products) using a double-channel disintegrations per minute (dpm) program.

Phospholipids of lamellar-body fraction. For evaluating the surfactant pool size, cells cultured on EHS matrix in $10 \mathrm{~cm}$ Petri culture dishes were collected after $48 \mathrm{~h}$ for extraction of a subcellular lamellar-body fraction through density-gradient fractionation (7). Lipids were extracted from the fraction, and aliquot fractions were used for direct determination of total phospholipid (TPL) content or for separation of sat-PC as above; quantification of TPL and sat-PC was performed through phosphate determination in mineralized samples (7). 
RNA isolation, RT-PCR amplification and Northern analysis. Total RNA was extracted from cultured cells (recovered with Matrisperse), and from rat lung and brain used as positive controls, by Trizol reagent (Invitrogen). Purity was checked by the ratio of 260 to $280 \mathrm{~nm}$ absorptions. For VEGFR2 mRNA detection, reverse transcription was performed on $2 \mu \mathrm{g}$ of RNA extracts with AMV Reverse Transcriptase (Promega) for first strand cDNA synthesis, and PCR amplification was obtained in the presence of specific primer pairs (forward primer: 5'-CGATGTCTCCTCCATCGTTT-3'; reverse primer: 5'-TTCCATCCGGAACAAATCTC-3' as described previously by Maurer et al. [24]) and Tfl polymerase (Promega) in a protocol of initial denaturation at $94^{\circ} \mathrm{C}$ for $2 \mathrm{~min}, 35$ cycles of amplification with denaturation at $94^{\circ} \mathrm{C}$ for $30 \mathrm{~s}$, annealing at $60^{\circ} \mathrm{C}$ for $1 \mathrm{~min}, 2 \mathrm{~min}$ at $68^{\circ} \mathrm{C}$, and final extension for $7 \mathrm{~min}$. Amplification products were visualized by $1 \%$ agarose gel electrophoresis. For Northern-blot evaluation of the steady-state level of surfactant protein transcripts, RNA, $25 \mu \mathrm{g}$ per sample, was fractionated by electrophoresis through $1 \%$ agarose/2.2M formaldehyde gels and blotted onto nylon membranes (Gene Screen, PerkinElmer). SP-A, SP-B, and SP-C complementary DNA (cDNA) probes were amplified by RT-PCR from adult rat lung RNA as described previously (7). Region 40-253 of SP-D cDNA was similarly amplified using sense orientation primer 5'-CAACCCTGAGAGTCCCATAGGTC-3', antisense orientation primer 5'CTCCATGCTTGTCCTGCTTGTAC-3', and 30 cycles of amplification with an annealing temperature of $52^{\circ} \mathrm{C}$ for $1 \mathrm{~min}$, extension at $72^{\circ} \mathrm{C}$ for $1 \mathrm{~min}$, and denaturation at $94^{\circ} \mathrm{C}$ for 1 $\min (17)$. cDNA probes were purified and labeled with $\left[\alpha^{-32} \mathrm{P}\right] \mathrm{dCTP}$ (NEN, PerkinElmer) as described (7). Conditions for prehybridization, hybridization, and stripping of blots were as described previously (16). To allow correction for variations in gel loading, the blots were also hybridized with an $18 S$ ribosomal DNA probe. Autoradiograms were obtained from exposure of blots at $-80^{\circ} \mathrm{C}$ to X-ray films (X-Omat Kodak Scientific Imaging Film, Eastman Kodak Co, Rochester, N.Y.). Quantification of signal intensity was performed by densitometric analysis of autoradiograms using the $\mathrm{NIH}$ image program. 


\section{RESULTS}

Detection of VEGF receptor transcript and protein in type // cells. Immunoreactive VEGFR2 have been demonstrated in human fetal lung type II cells (5). To determine whether these receptors were expressed also in rat type II cells and persisted during culture, they were searched for at the pre- and post-translational levels. VEGFR2 transcripts were detected by RT-PCR amplification in cultured cells as in whole lung or brain (Fig. 1-A). Protein analysis by Western blot showed the presence of the receptor in cultured cells independently of the presence of VEGF (Fig. 1-B). Frozen sections of freshly isolated cells, or cells cultured for 48h on EHS matrix in control medium, were immunostained for VEGFR2 antigen. No labeling was obtained from both negative controls (saturation of receptors with VEGF, Fig. 2A, and omission of primary antibody, Fig. $2 \mathrm{~B}$ and $2 \mathrm{C}$ ). Positive immunolabeling clearly evidenced the presence of the receptor at the periphery of most of the cultured cells with DAB staining (Fig. 2D) as well as with FITC labeling (Fig. 2E). Freshly isolated cells were also positively labeled (not shown). The double labeling of cultured cells with anti-VEGFR2 antibody and either anti-SP-A or anti-SP-B antibody clearly demonstrated that the receptor was actually expressed by cells that all displayed characteristic features of alveolar type II cells (Fig.3).

Absence of endothelial cells in type /l cell preparations. To determine whether endothelial cells contaminated fetal type II cell preparations, freshly isolated type II cells were labeled with an antibody raised against the endothelial cell marker CD31. No immunostaining was observed, indicating that the preparations were free of endothelial cells (Fig.4A), which validates findings from the RT-PCR amplification and Western blot analysis of VEGFR2 transcripts. The anti-CD31 antibody strongly labeled vessels in whole rat lung sections used as positive control (Fig. 4B). 
$\left[{ }^{3} \mathrm{H}\right]$-Thymidine incorporation into DNA and BrdU labeling of cultured type I/ cells. In previous study (5), VEGF had been reported to enhance BrdU incorporation into type II cells of human fetal lung explants at concentrations 50 and $100 \mathrm{ng} / \mathrm{ml}$. In the present study, the effects of VEGF on isolated type II cells were tested both through the study of $\left[{ }^{3} \mathrm{H}\right]$-thymidine incorporation and BrdU incorporation. The choice of plastic as cell substratum was made because cells cultured on EHS matrix have been reported to grow poorly. Dose-response analysis on $\left[{ }^{3} \mathrm{H}\right]$-thymidine incorporation by isolated type II cells was tested for VEGF concentrations ranging from 10 to $100 \mathrm{ng} / \mathrm{ml}$. No concentration induced a significant change as compared with control conditions (Fig. 5) whereas KGF $50 \mathrm{ng} / \mathrm{ml}$ tested in parallel as positive control increased thymidine incorporation 4.5 times (Fig. 5). Similarly, no appreciable change in the proportion of BrdU-labeled cells was observed in the presence of VEGF (Fig. 6). On a total of 500-600 counted cells for each condition, the proportion of labeled cells was $9.2 \%, 6.3 \%, 9.4 \%$ and $7.6 \%$ in control condition and in the presence of VEGF 25,50 , and $100 \mathrm{ng} / \mathrm{ml}$, respectively.

$\left[{ }^{3} \mathrm{H}\right]$-Choline incorporation in sat-PC and phospholipid content of lamellar-body fraction. As shown in Fig. $7 \mathrm{~A},\left[{ }^{3} \mathrm{H}\right]$-choline incorporation was significantly increased $(+27 \%)$ only in the presence of VEGF $50 \mathrm{ng} / \mathrm{ml}$. No significant change was observed either for VEGF $25 \mathrm{ng} / \mathrm{ml}$ or for VEGF $100 \mathrm{ng} / \mathrm{ml}$. The surfactant pool size estimated by TPL and sat-PC content of sub-cellular lamellar-body fraction extracted from cultured cells was therefore determined only in the presence of the VEGF concentration that had increased $\left[{ }^{3} \mathrm{H}\right]$-choline incorporation, i.e. $50 \mathrm{ng} / \mathrm{ml}$. Significant change was observed neither for TPL nor for sat-PC amount of LB fraction in cells cultured in the presence of VEGF (Fig. 7B), indicating an absence of change in pool size of surfactant phospholipids.

Steady-state level of SP-A, $-B,-C$, and $-D$ transcripts. RNA was extracted from cells cultured on EHS matrix and exposed to VEGF 50 or $100 \mathrm{ng} / \mathrm{ml}$ for $48 \mathrm{~h}$. As depicted in Fig. 8A, Northern blotting analysis indicated that VEGF did not change significantly the expression 
level of SP-A, SP-C, and SP-D transcripts, whatever the concentration. By contrast, SP-B transcript steady-state level was increased 4-fold by VEGF $100 \mathrm{ng} / \mathrm{ml}(\mathrm{p}<0.001)$, VEGF 50 $\mathrm{ng} / \mathrm{ml}$ being without effect (Fig. 8A-B). This increase was not reflected, however, by an increase in the SP-B cell content after $48 \mathrm{~h}$ as assessed by Western blotting (Fig. 8C).

Effect of VEGF on the in vitro transdifferentiation of alveolar type II into type I cells. Isolated type II cells were maintained for 3 days on plastic, a condition formerly shown to favor their transdifferentiation into type I cells (9). The cell-surface protein T1 $\alpha$ was used as a specific marker of type I cells (36) to follow the process of differentiation during the course of culture. T1 $\alpha$ immunolabeling that was negative in cells at the issue of overnight adhesion to the substratum (Fig. 9A) appeared during culture (Fig. 9B-C). Whereas in control medium, strong T1 $\alpha$ immunolabeling was observed with similar intensity both at $48 \mathrm{~h}$ (Fig. 9B) and $72 \mathrm{~h}$ (Fig. $9 \mathrm{C}$ ) of culture, in the presence of VEGF 50 or $100 \mathrm{ng} / \mathrm{ml}$ it was noticeably weaker at $48 \mathrm{~h}$ (Fig. 9D-E), but not at 72h (Fig. 9F). Therefore, although VEGF somewhat delayed the appearance of the marker, it did not prevent cell transdifferentiation that seemed to be completed at time $72 \mathrm{~h}$ despite the continuous presence of VEGF.

\section{DISCUSSION}

Previous investigations run in vitro with fetal lung explants or in vivo suggested that alveolar type II cells, that are the major pulmonary source of VEGF, might also represent targets for this growth factor. Our investigation run with primary cultures of isolated type II cells shows much more modest effects of exogenous VEGF suggestive of indirect action of the latter in previous studies.

Consistent with previous findings in humans (5) we detected immunoreactive VEGFR2 in type II cells from fetal rat lung, the presence of which persisted during culture. Moreover, we demonstrated the presence of the transcript, which, along with the absence of detection of CD31-positive cells in epithelial cell preparations, argues for actual expression of this 
receptor in fetal type II cells. Expression of another receptor of VEGF, VEGFR1 (Flt-1), was also reported in alveolar type II cells in the adult rat (12) as well as in the human fetus (22). Marked increases of epithelium volume density and BrdU uptake by epithelial cells have been evidenced in fetal lung explants exposed to VEGF, both being suggestive of a role of VEGF as an epithelial cell growth factor (5). In the present experiments, the same recombinant VEGF at same concentrations failed to induce any increase in thymidine or BrdU incorporation in isolated type II cells, which, by contrast, responded strongly to KGF, consistent with previous findings in adult $(26,35)$ as well as fetal $(7)$ type II cells. Our findings therefore suggest that the proliferative effects of VEGF previously observed in lung explants were indirect. Consistent with the assumption that VEGF does not control directly alveolar cell proliferation is the finding that the VEGF receptor inhibitor SU5416 chronically given to rats induced alveolar septal cell apoptosis, but did not inhibit lung cell proliferation (21).

VEGF increased the rate of $\left[{ }^{3} \mathrm{H}\right]$-choline incorporation less than one third in whole-cell sat-PC of isolated type II cells grown on EHS matrix. Comparatively, this effect was much less pronounced than those previously reported for EGF and KGF in the same experimental conditions (7). Moreover, VEGF failed to increase the TPL and sat-PC contents of a lamellarbody fraction that were by contrast considerably increased by EGF and KGF (7). Although sat-PC is representative of surfactant of which it is the most abundant component, it is not exclusive of surfactant, but is also present in lower proportion in other sub-cellular membrane compartments. The absence of change in lamellar-body fraction in VEGF-treated cells suggests that increased choline incorporation may essentially represent stimulation of synthesis of non-surfactant sat-PC. This appears consistent with the previous finding that VEGF did not enhance choline incorporation in sat-PC in human lung explants, whereas it enhanced it in total PC more representative of non-surfactant phospholipids (5). Although total PC was found to be reduced in whole lung of $\mathrm{HIF}-2^{-1-}$ mice (8), surfactant compartment was not explored specifically in this model, and it is not clear whether this was related directly to the observed reduction of VEGF production, nor whether the prevention of neonatal respiratory distress observed following intra-amniotic administration of VEGF was linked to 
an increase in surfactant phospholipids. Reduced glycogen stores after VEGF treatment were interpreted by the authors as an improved maturation of the lung and as the result of a probable utilization for surfactant phospholipid synthesis (8), because glycogen has been demonstrated to be a precursor of the latter (10). However, improved morphological maturation of the lung (i.e. thinning of septa) after VEGF treatment evidenced by histological examination (8) is likely to have played also an important role in the prevention of respiratory distress. An actual increase of surfactant production by VEGF in the HIF-2 $2^{-1}$ mouse model therefore remains to be established, but even if it actually occurred, it is likely to have resulted from an indirect effect of VEGF treatment.

As regards expression of surfactant proteins, previous findings have not been fully consistent. Brown et al. (5) reported enhanced SP-A and SP-C expression in fetal lung explants, but unchanged SP-B expression, whereas Compernolle et al. (8) reported enhanced SP-B and SP-C transcripts in isolated adult type II cells. In the present study, VEGF strongly enhanced SP-B expression in isolated type II cells, although this was seen only at the highest tested concentration, but failed to enhance that of SP-A, SP-C, and also SP-D not explored in previous studies. These results are in agreement only with the RT-PCR data from Compernolle et al. about SP-B (8). It should be underlined that in those previous experiments, SP-B expression was more markedly stimulated than that of SP-C. Whatsoever, it appears from both the present and previous (8) findings that VEGF is able to exert a direct stimulating effect on the expression level of the SP-B transcript in isolated type II cells. Despite the extent of this increase at the pre-translational level, we did not detect an increase of SP-B protein content after 48h of exposure to VEGF. This may either be due to absence of stimulation of SP-B synthesis, or to a delay between transcript and protein responses, or to a release of SP-B in the medium.

In addition to surfactant synthesis and secretion, a major function of alveolar type II cells is to serve as precursors of type I cells, the alveolar epithelial cells that perform respiratory gas 
exchanges (2). Zeng et al. (37) have demonstrated by electron microscopy observation that overexpression of VEGF targeted on the developing pulmonary epithelium in transgenic mice resulted in a lack of type I cell differentiation, whereas the immunostaining for SP-C and Clara cell secretory protein was normal. Hence, in this model, type II cell characteristics might have remained normal whereas their differentiation into type I cells was inhibited. In order to determine whether exogenous VEGF would interfere with the in vitro transformation of type II into type I cells, isolated type II cells were cultured for $72 \mathrm{~h}$ on plastic, a condition well established for favoring this transdifferentiation (9). The appearance of the type I cell marker T1 $\alpha$ during culture evidenced the in vitro acquisition of type I cell features. T1 $\alpha$ immunostaining was weaker after $48 \mathrm{~h}$ of culture in the presence of VEGF, but this was no longer seen after 72h. Consistent with previous observations (37), VEGF therefore exerted some inhibiting effect on the in vitro transdifferentiation, but this led only to retard, not to prevent the phenomenon. Possibly, the concentration of VEGF in culture medium was insufficient to achieve the preventive effect against type I cell differentiation observed in transgenic mice. This inhibiting effect of VEGF suggests that local VEGF concentration in the developing lung may contribute to orient alveolar epithelial cells toward either type I or type II phenotype.

Finally, our results indicate that although VEGF receptors are present on type II cells, VEGF, at least the isoform that was used herein, does not exert on isolated cells all the effects that were observed with the same recombinant VEGF in lung explants that contained the other lung cell types. With the exception of a possible role in the control of SP-B expression, a major role of autocrine control mechanisms of type II cell growth and maturation through VEGF signaling is therefore questionable. Especially, VEGF does not appear, at least in the rat, to be an autocrine stimulus of type II cell proliferation contrary to previous assumption in humans (5). The apparent discrepancy between our and previous findings may indeed reflect interspecies differences, i.e. VEGF would not have the same effects on rat and human lung cells. Nevertheless, that human recombinant VEGF would have been more efficient in 
homologous system (human lung explants, 5) but would not have stimulated rat type II cell proliferation because of interspecies differences in responsiveness is unlikely, since (i) it has already been shown previously to exert a variety of biological effects on rat cells $(3,34,38)$ and (ii) human recombinant VEGF strongly increased rat SP-B transcripts and delayed type I cell differentiation. The functional significance of the presence of VEGF receptors on type II cells therefore remains poorly defined.

The assumption that autocrine control is not a major mechanism in alveolar cell development is consistent with the paradigm of a requirement for a paracrine control by lung mesenchyme for both growth and differentiation of lung epithelial cells (reviewed in 29). Thus, distal lung mesenchyme is able to induce growth and branching of the tracheal epithelium and to reorient its differentiation toward an alveolar phenotype (31). Investigations in mesenchymefree cultures have evidenced the prominent role of factors of the fibroblast growth factor family, namely FGF-1 and FGF-7 (KGF), in these processes (30). These paracrine mechanisms that play crucial role during development $(6,7)$ appear to be maintained throughout life (32). A possible interpretation of the previously evidenced effects of VEGF on fetal lung explants (5) or on mouse lung in vivo (8) is a stimulation of mesenchymal and/or endothelial cells by VEGF to produce mediators that would in turn exert stimulating effects on alveolar type II cell proliferation and maturation. In conclusion, the present investigation does not get back into question the crucial importance of VEGF for the development of pulmonary structure, but as far as growth and maturation of alveolar epithelial cells are concerned, it suggests that VEGF effects are mostly exerted indirectly through reciprocal paracrine interactions involving other cell types. 


\section{REFERENCES}

1. Acarregui MJ, Penisten ST, Goss KL, Ramirez K, and Snyder JM. Vascular endothelial growth factor gene expression in human fetal lung in vitro. Am J Respir Cell Mol Biol 20:1423, 1999.

2. Adamson IYR, Bowden DH. Derivation of type 1 epithelium from type 2 cells in the developing rat lung. Lab invest 32: 736-745, 1975.

3. Asahara T, Bauters C, Pastore C, Kearney M, Rossow S, Bunting S, Ferrara N, Symes JF, and Isner JM. Local delivery of vascular endothelial growth factor accelerates reendothelialization and attenuates intimal hyperplasia in balloon-injured rat carotid artery. Circulation 91:2793-801, 1995.

4. Bhatt AJ, Pryhuber GS, Huyck H, Watkins RH, Metlay LA, and Maniscalco WM. Disrupted pulmonary vasculature and decreased vascular endothelial growth factor, Flt-1, and TIE-2 in human infants dying with bronchopulmonary dysplasia. Am J Respir Crit Care Med 164:1971-1980, 2001.

5. Brown KR, England KM, Goss KL, Snyder JM, and Acarregui MJ. VEGF induces airway epithelial cell proliferation in human fetal lung in vitro. Am J Physiol Lung Cell Mol Physiol 281:L1001-L1010, 2001.

6. Chelly N, Henrion A, Pinteur C, Chailley-Heu B, and Bourbon JR. Role of keratinocyte growth factor in the control of surfactant synthesis by fetal lung mesenchyme. Endocrinology 142:1814-1819, 2001.

7. Chelly N, Mouhieddine-Gueddiche OB, Barlier-Mur AM, Chailley-Heu B, and Bourbon JR. Keratinocyte growth factor enhances maturation of fetal rat lung type II cells. Am J Respir Cell Mol Biol 20:423-32, 1999.

8. Compernolle V, Brusselmans K, Acker T, Hoet P, Tjwa M, Beck H, Plaisance S, Dor Y, Keshet E, Lupu F, Nemery B, Dewerchin M, Van Veldhoven P, Plate K, Moons L, Collen D, Carmeliet P. Loss of HIF-2alpha and inhibition of VEGF impair fetal lung maturation, whereas treatment with VEGF prevents fatal respiratory distress in premature mice. Nat Med 8:702-710, 2002. 
9. Danto SI, Zabski SM, Crandall ED. Reactivity of alveolar epithelial cells in primary culture with type I cell monoclonal antibodies. Am J Respir Cell Mol Biol 6:296-306, 1992.

10. Farrell PM, and Bourbon JR. Fetal lung surfactant lipid synthesis from glycogen during organ culture. Biochim Biophys Acta 878:159-167, 1986.

11. Fehrenbach H. Alveolar epithelial type II cell: defender of the alveolus revisited. Respir Res. 2:33-46, 2001.

12. Fehrenbach H, Haase M, Kasper M, Koslowski R, Schuh D, Muller M. Alterations in the immunohistochemical distribution patterns of vascular endothelial growth factor receptors Flk1 and Flt1 in bleomycin-induced rat lung fibrosis. Virchows Arch 435:20-31, 1999.

13. Ferrara N, Carver-Moore K, Chen H, Dowd M, Lu L, O'Shea KS, Powell-Braxton L, Hillan KJ, and Moore MW. Heterozygous embryonic lethality induced by targeted inactivation of the VEGF gene. Nature 380:439-442, 1996.

14. Fraslon C, and Bourbon JR. Comparison of effects of epidermal and insulin-like growth factors, gastrin releasing peptide and retinoic acid on fetal lung cell growth and maturation in vitro. Biochim Biophys Acta 1123:65-75, 1992.

15. Fraslon C, Lacaze-Masmonteil T, Zupan V, Chailley-Heu B, and Bourbon JR. Fetal rat lung type II cell differentiation in serum-free isolated cell culture: modulation and inhibition. Am J Physiol Lung Cell Mol Physiol 264:L504-L516, 1993.

16. Fraslon-Vanhulle C, Chailley-Heu B, Batenburg JJ, Elfring R, and Bourbon JR. Ontogeny of surfactant proteins and lipid-synthesizing enzymes in cultured fetal lung epithelial cells. Am J Physiol Lung Cell Mol Physiol 267:L375-L383, 1994.

17. Fisher JH, Mason R. Expression of pulmonary surfactant protein D in rat gastric mucosa.Am J Respir Cell Mol Biol 12:13-18, 1995.

18. Gebb SA, and Shannon JM. Tissue interactions mediate early events in pulmonary vasculogenesis. Dev Dyn 217:159-169, 2000.

19. Healy AM, Morgenthau L, Zhu X, Farber HW, and Cardoso WV. VEGF is deposited in the subepithelial matrix at the leading edge of branching airways and stimulates neovascularization in the murine embryonic lung. Dev Dyn 219:341-352, 2000. 
20. Jakkula M, Le Cras TD, Gebb S, Hirth KP, Tuder RM, Voelkel NF, and Abman SH. Inhibition of angiogenesis decreases alveolarization in the developing rat lung. Am J Physiol Lung Cell Mol Physiol 279:L600-L607, 2000.

21. Kasahara Y, Tuder RM, Taraseviciene-Stewart L, Le Cras TD, Abman S, Hirth PK, Waltenberger J, and Voelkel NF. Inhibition of VEGF receptors causes lung cell apoptosis and emphysema. J Clin Invest 106:1311-1319, 2000.

22. Lassus P, Turanlahti M, Heikkila P, Andersson LC, Nupponen I, Sarnesto A, Andersson S. Pulmonary vascular endothelial growth factor and Flt-1 in fetuses, in acute and chronic lung disease, and in persistent pulmonary hypertension of the newborn. $A m J$ Respir Crit Care Med 164:1981-1987, 2001.

23. Le Cras TD, Markham NE, Tuder RM, Voelkel NF, and Abman SH. Treatment of newborn rats with a VEGF receptor inhibitor causes pulmonary hypertension and abnormal lung structure. Am J Physiol Lung Cell Mol Physiol 283:L555-L562, 2002.

24. Maurer MH, Tripps WKC, Feldmann RE Jr, Kuchinsky W. Expression of vascular endothelial growth factor and its receptor in rat neural stem cells. Neurosci Lett 344:165-168, 2003.

25. Ng YS, Rohan R, Sunday ME, Demello DE, and D'Amore PA. Differential expression of VEGF isoforms in mouse during development and in the adult. Dev Dyn 220:112-121, 2001.

26. Panos RJ, Rubin JS, Csaky KG, Aaronson SA, and Mason RJ. Keratinocyte growth factor and hepatocyte growth factor/scatter factor are heparin-binding growth factors for alveolar type II cells in fibroblast-conditioned medium. J Clin Invest 92:969-977, 1993.

27. Pham I, Uchida T, Planes C, Ware LB, Kaner R, Matthay MA, and Clerici C. Hypoxia upregulates VEGF expression in alveolar epithelial cells in vitro and in vivo. Am J Physiol Lung Cell Mol Physiol 283:L1133-L1142, 2002.

28. Rannels SR, Yarnell JA, Fisher CS, Fabisiak JP, and Rannels DE. Role of laminin in maintenance of type II pneumocyte morphology and function. Am J Physiol Cell Physiol 253:C835-C845, 1987. 
29. Shannon JM, and Deterding RD. Epithelial-mesenchymal interactions in lung development. In: Lung Growth and Development, edited by McDonald JA, New-York, NY:3. 30. Shannon JM, Gebb SA, and Nielsen LD. Induction of alveolar type II cell differentiation in embryonic tracheal epithelium in mesenchyme-free culture. Development 126:1675-1688, 1999.

31. Shannon JM, Nielsen LD, Gebb SA, and Randell SH. Mesenchyme specifies epithelial differentiation in reciprocal recombinants of embryonic lung and trachea. Dev Dyn 212:482494, 1998.

32. Shannon JM, Pan T, Nielsen LD, Edeen KE, and Mason RJ. Lung fibroblasts improve differentiation of rat type II cells in primary culture. Am J Respir Cell Mol Biol 24:235-244, 2001.

33. Shifren JL, Doldi N, Ferrara N, Mesiano S, and Jaffe RB. In the human fetus, vascular endothelial growth factor is expressed in epithelial cells and myocytes, but not vascular endothelium: implications for mode of action. J Clin Endocrinol Metab 79:316-322, 1994.

34. Thuringer D, Maulon L, and Frelin C. Rapid transactivation of the vascular endothelial growth factor receptor KDR/Flk-1 by the bradykinin B2 receptor contributes to endothelial nitric-oxide synthase activation in cardiac capillary endothelial cells. J Biol Chem 277:20282032, 2002.

35. Ulich TR, Yi ES, Longmuir K, Yin S, Biltz R, Morris CF, Housley RM, and Pierce GF. Keratinocyte growth factor is a growth factor for type II pneumocytes in vivo. J Clin Invest 93:1298-306, 1994.

36.Williams MC. Alveolar type I cells: molecular phenotype and development. Annu Rev Physiol 65: 669-695, 2003.

37. Zeng X, Wert SE, Federici R, Peters KG, Whitsett JA. VEGF enhances pulmonary vasculogenesis and disrupts lung morphogenesis in vivo. Dev Dyn 211:215-227, 1998.

38. Zhang ZG, Zhang L, Jiang Q, Zhang R, Davies K, Powers C, Bruggen N, and Chopp M. VEGF enhances angiogenesis and promotes blood-brain barrier leakage in the ischemic brain. J Clin Invest 106:829-838, 2000. 


\section{FIGURE LEGENDS}

Fig.1. Expression of VEGFR2 RNA and protein in fetal alveolar type II cells. A: Identification of RT-PCR amplification products of VEGFR2/Flk1 transcripts in total RNA extracts from rat tissues and from fetal lung type II cells cultured for 48h on EHS matrix in control medium. Lane 1: DNA ladder. Lane 2: rat lung. Lane 3: rat brain. Lanes 4-6: type II cells (from 3 different cultures). A unique amplification product was observed for all extracts at the expected size. B: Western blot analysis of VEGFR2 protein under reducing conditions in fetal alveolar type II cells cultured on EHS matrix for 48h in control medium or in the presence of VEGF. Data are representative of 3 samples/VEGF concentration. VEGFR2 protein expression was not changed by VEGF treatment.

Fig. 2. Immunolabeling of VEGFR2 in type II cells cultured for 48h on EHS matrix in control medium. Frozen sections were incubated with anti-VEGFR2 monoclonal antibody revealed with $\mathrm{DAB}(\mathrm{A}, \mathrm{B}, \mathrm{D})$ or FITC $(\mathrm{C}, \mathrm{E})$ staining. DAB-stained sections were counterstained with hematoxylin that appears as uniform low blue. A, B and C: negative controls obtained by saturation with rhVEGF $(A)$ or by omitting the primary monoclonal antibody $(B, C)$. D: VEGFR2 DAB-immunostaining of cultured cells appears as brown punctuated stain at the cell periphery. E: VEGFR2 immunofluorescent labeling at the periphery of cultured cells.

Fig.3. Double immunolabeling of surfactant proteins SP-A (A) and SP-B (B) (FITC fluorescence), and of VEGFR2 (B and D, rhodamine fluorescence) in type II cells cultured for 48h on EHS matrix in control medium. Surfactant proteins co-localized with VEGFR2.

Fig. 4. Labeling of freshly isolated type II cells for the endothelial cell marker CD31 (PECAM1) (DAB immunostaining). A: Frozen section of type II cells; no signal was detected indicating the absence of endothelial cells. B: positive control; vessels labeled for CD31 in a section of adult rat lung parenchyma. 
Fig. 5. Comparative effects of VEGF and KGF on $\left[{ }^{3} \mathrm{H}\right]$-thymidine incorporation into DNA of isolated fetal alveolar type II cells cultured on plastic for 48h. VEGF did not induce significant change at any of the tested concentrations whereas KGF $50 \mathrm{ng} / \mathrm{ml}$ enhanced incorporation about 4.5 times as compared with that in control defined medium containing no growth factor. Mean \pm sem on 8 independent determinations; ${ }^{* * *}$ significantly different from control medium for $p<0.001$.

Fig. 6. BrdU incorporation by fetal alveolar type II cells cultured on Sonic seal slide wells in the absence (A, control) or in the presence of VEGF $25 \mathrm{ng} / \mathrm{ml}(B), 50 \mathrm{ng} / \mathrm{ml}(C)$ or $100 \mathrm{ng} / \mathrm{ml}$ (D). Nuclei of proliferating cells that incorporated BrdU appear as bright points. For evaluating the proportion of BrdU incorporating cells, all cell nuclei were stained by dye Hoechst 33258 (low-gray points). Representative fields are presented. No appreciable difference was observed for cells grown in the presence or absence of VEGF.

Fig. 7. Effects of VEGF on surfactant phospholipid biosynthesis. A: Effects of VEGF on $\left[{ }^{3} \mathrm{H}\right]-$ choline incorporation into saturated phosphatidylcholine (sat-PC) of type II cells cultured on EHS matrix for $48 \mathrm{~h}$. VEGF enhanced incorporation at concentration $50 \mathrm{ng} / \mathrm{ml}$ only. Mean \pm sem on 8 independent determinations for each experimental condition; *significantly different from control medium for $\mathrm{p}<0.05$. $\mathrm{B}$ : Total phospholipid (TPL) and saturated phosphatidylcholine (Sat-PC) content of lamellar body (LB) fraction isolated from type II cells cultured on EHS matrix for $48 \mathrm{~h}$ in control medium or in the presence of VEGF $50 \mathrm{ng} / \mathrm{ml}$. Mean \pm sem on 8 independent cell samples for each experimental condition. No difference is statistically significant.

Fig. 8. Northern blot analysis of transcripts of surfactant proteins (SP) - A, -B, -C and -D and Western blot analysis of SP-B in fetal alveolar type II cells cultured on EHS matrix for 48h in control medium or in the presence of VEGF. A: Example of a Northern blot obtained with SP- 
B cDNA probe evidencing the marked increase in the presence of VEGF $100 \mathrm{ng} / \mathrm{ml}$. B: Densitometric analysis; results are expressed as percentage of the average control level after normalization for RNA loading on the basis of hybridization of $18 \mathrm{~S}$ rRNA (mean \pm SEM on 7 independent cell samples for each experimental condition; significant difference from control medium for $\left.{ }^{* * *} p<0.001\right)$. C: Western blot analysis under non-reducing conditions detected SP-B protein with relative molecular weight $=18,000 ; \beta$ actin was used as a protein loader control. Data are representative of 3 samples/VEGF concentration. SP-B protein expression was not distinctly changed by VEGF.

Fig. 9. Effect of VEGF treatment on the in vitro transdifferentiation of alveolar type II cells. Isolated cells were seeded on plastic and cultured for up to $72 \mathrm{~h}$ in the presence or absence of VEGF 50 and $100 \mathrm{ng} / \mathrm{ml}$. Transdifferentiation of type II into type I cells was assessed by the appearance during culture of the type I-cell marker T1 $\alpha$ (FITC staining). Each field is representative of 3 experiments. A: absence of staining in epithelial cells after overnight adhesion to plastic (referred to as t0 of culture). B-C: cells cultured in control medium for $48 \mathrm{~h}$ and $72 \mathrm{~h}$, respectively; T1 $\alpha$ was strongly expressed at both stages. D-E: cells cultured for $48 \mathrm{~h}$ in the presence of VEGF 50 and $100 \mathrm{ng} / \mathrm{ml}$, respectively; T1 $\alpha$ immunofluorescence was obviously reduced as compared with control medium. F: cells cultured for $72 \mathrm{~h}$ in the presence of $100 \mathrm{ng} / \mathrm{ml} ; \mathrm{T} 1 \alpha$ immunofluorescence was similar to that in control medium. VEGF appeared to delay, but not to prevent the in vitro transdifferentiation of alveolar type II into type I cells. 


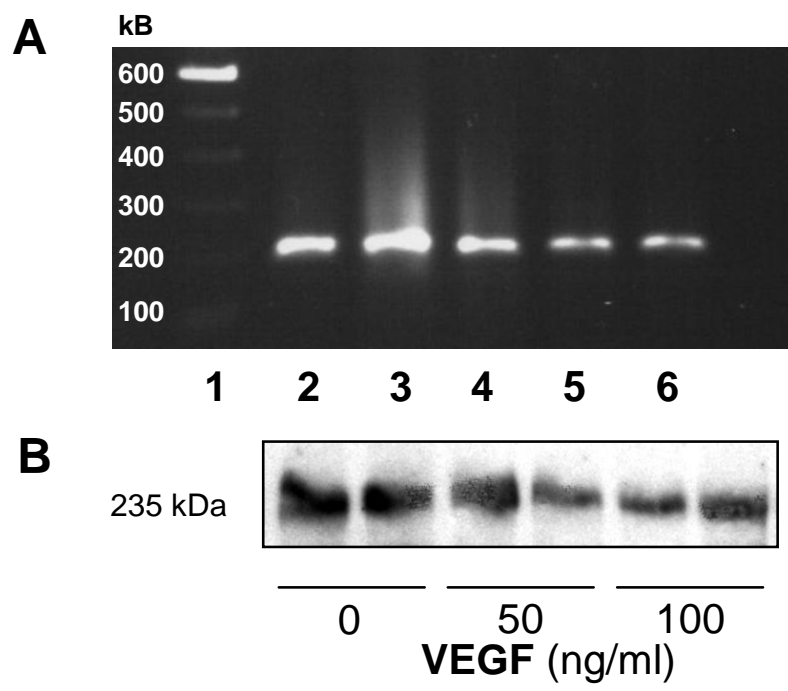

Figure 1
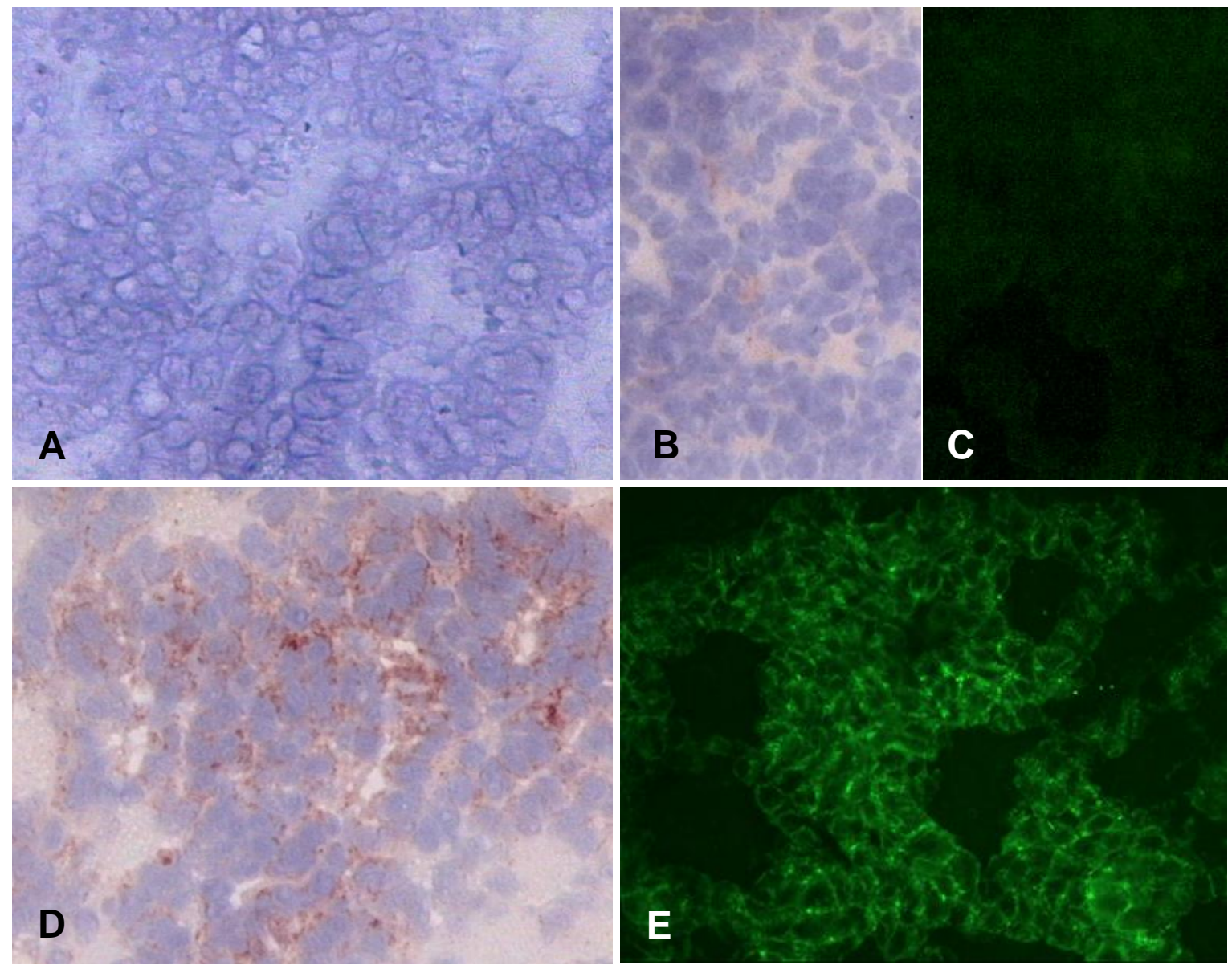

Figure 2 


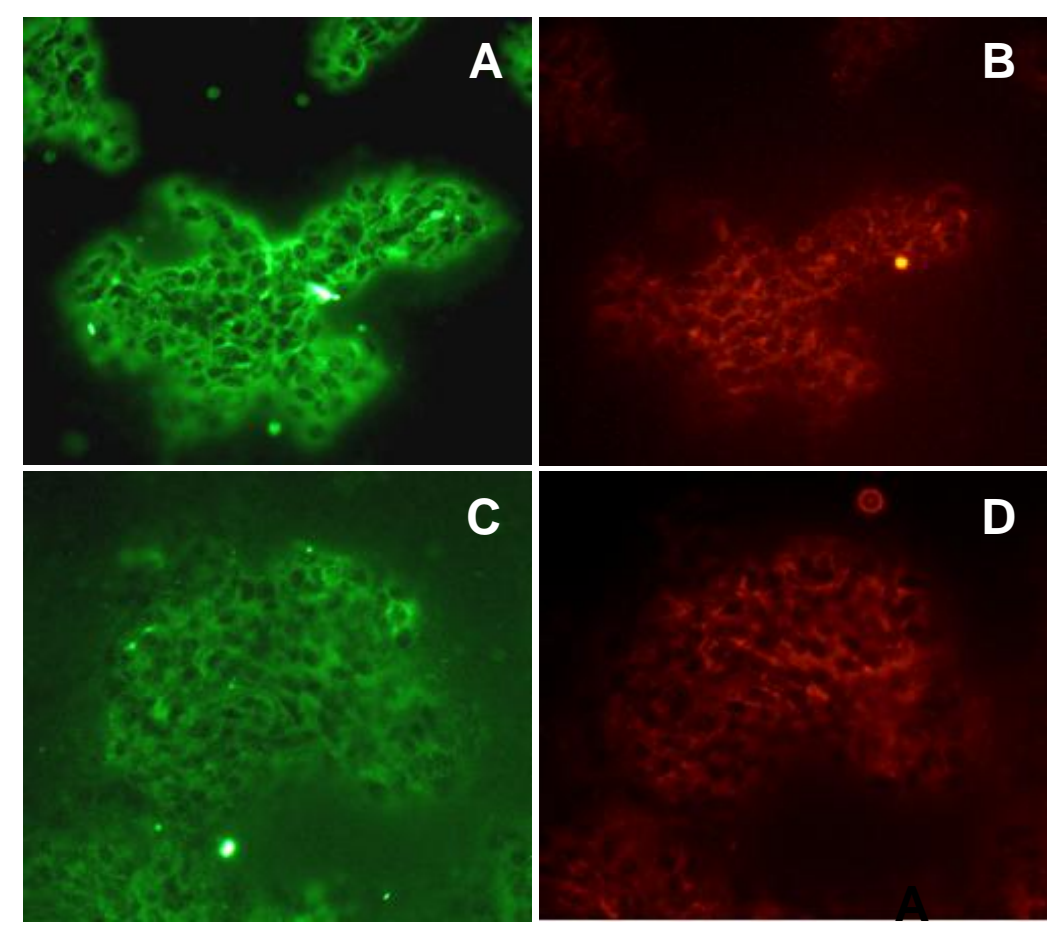

Figure 3

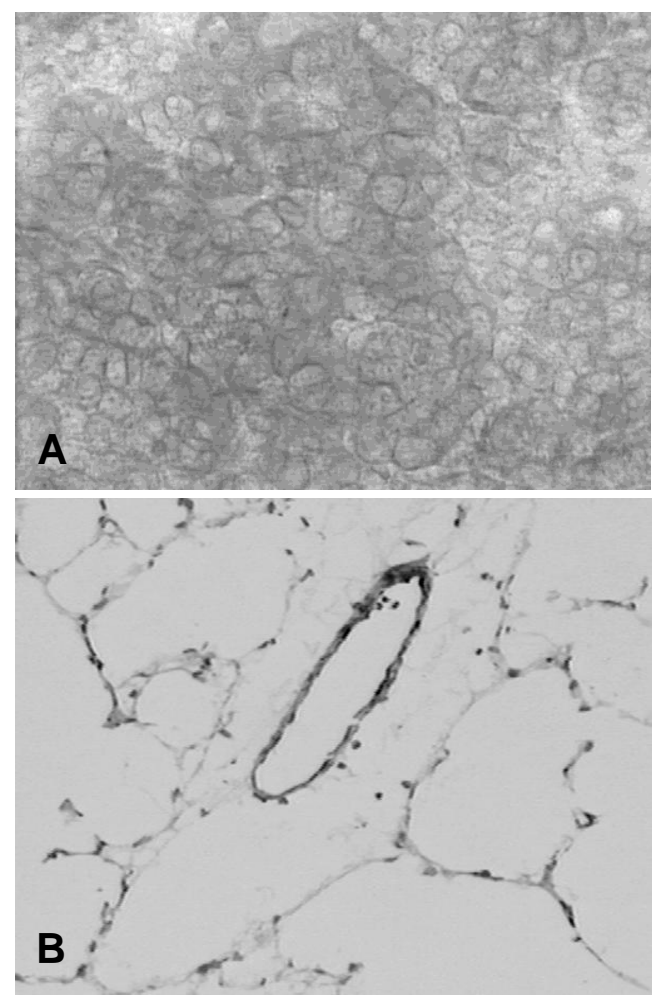

Figure 4 


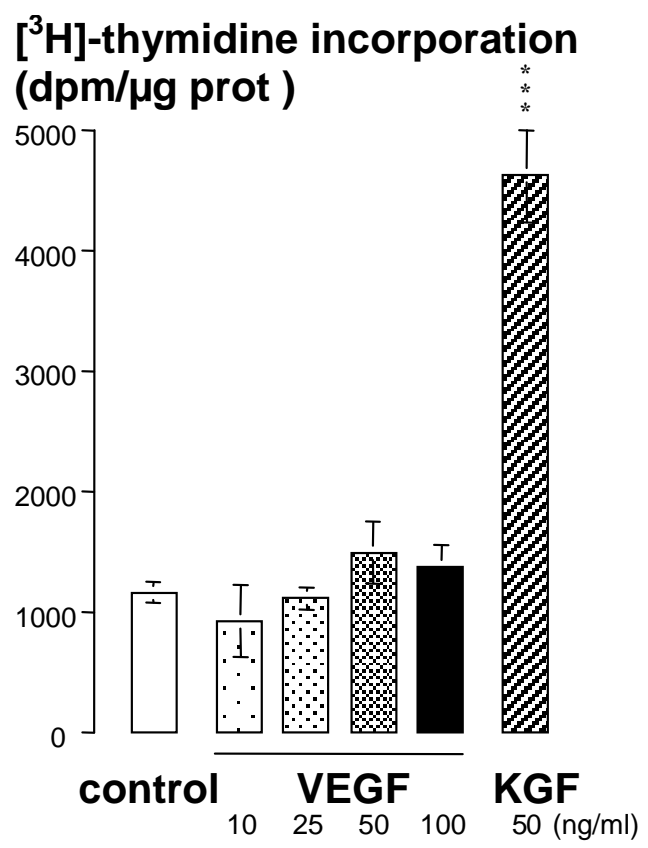

Figure 5
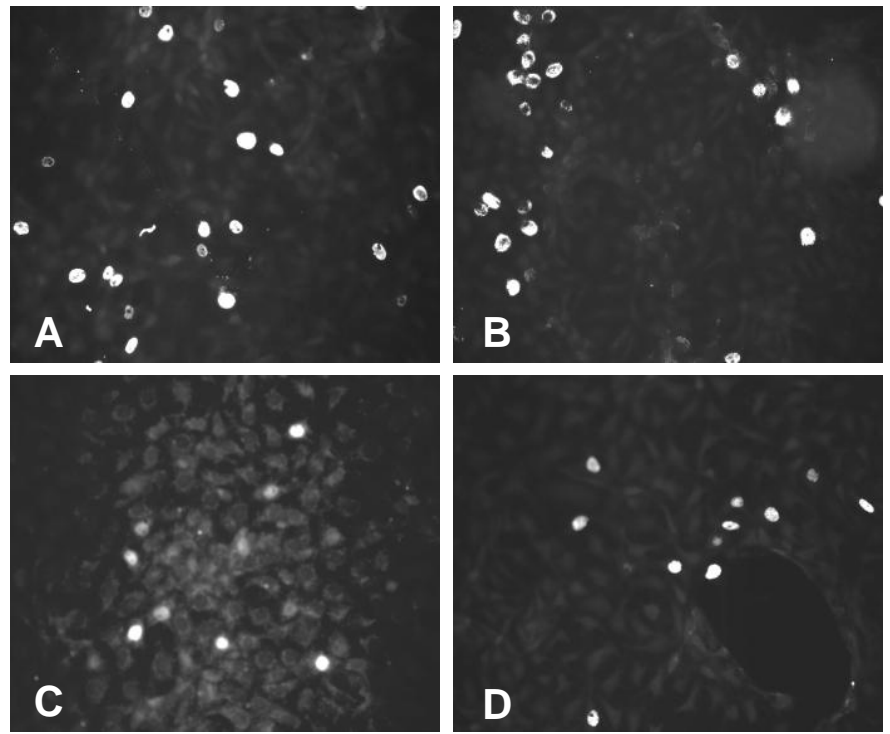

Figure 6 


\section{A}

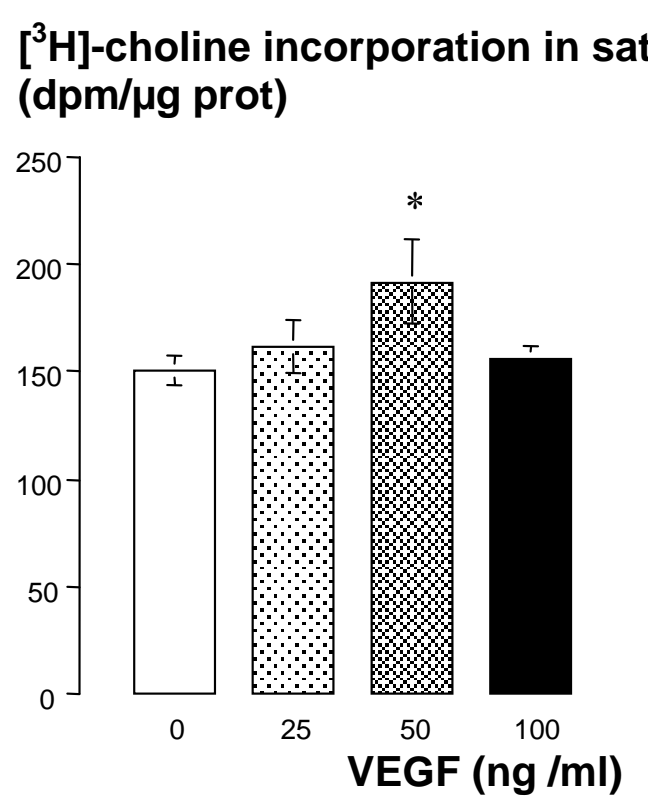

B

Phospholipids of LB fraction

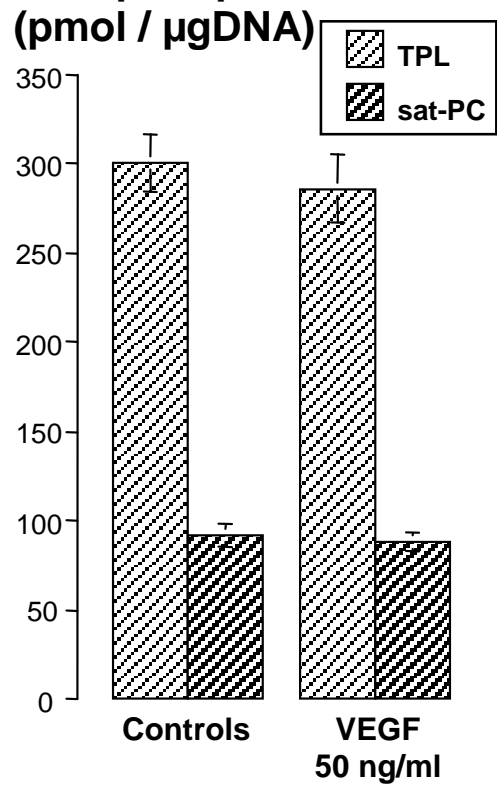

Figure 7 


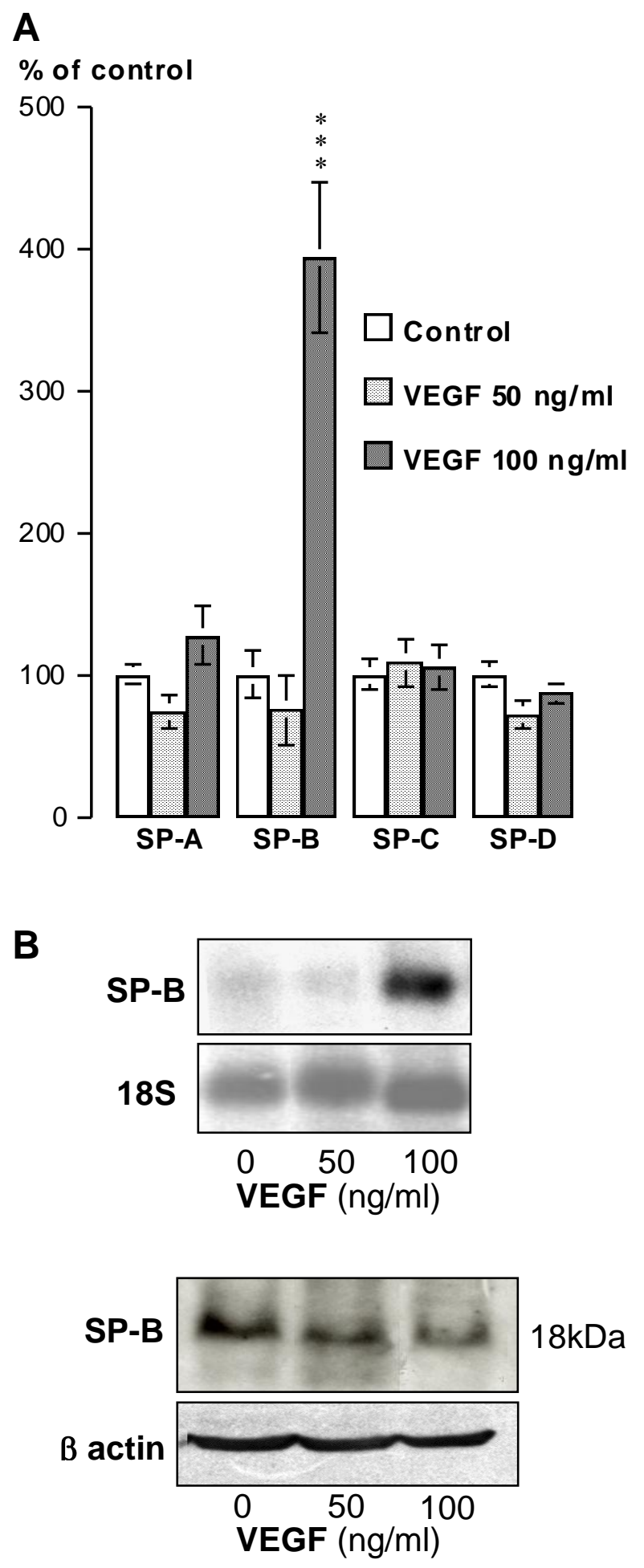

Figure 8 

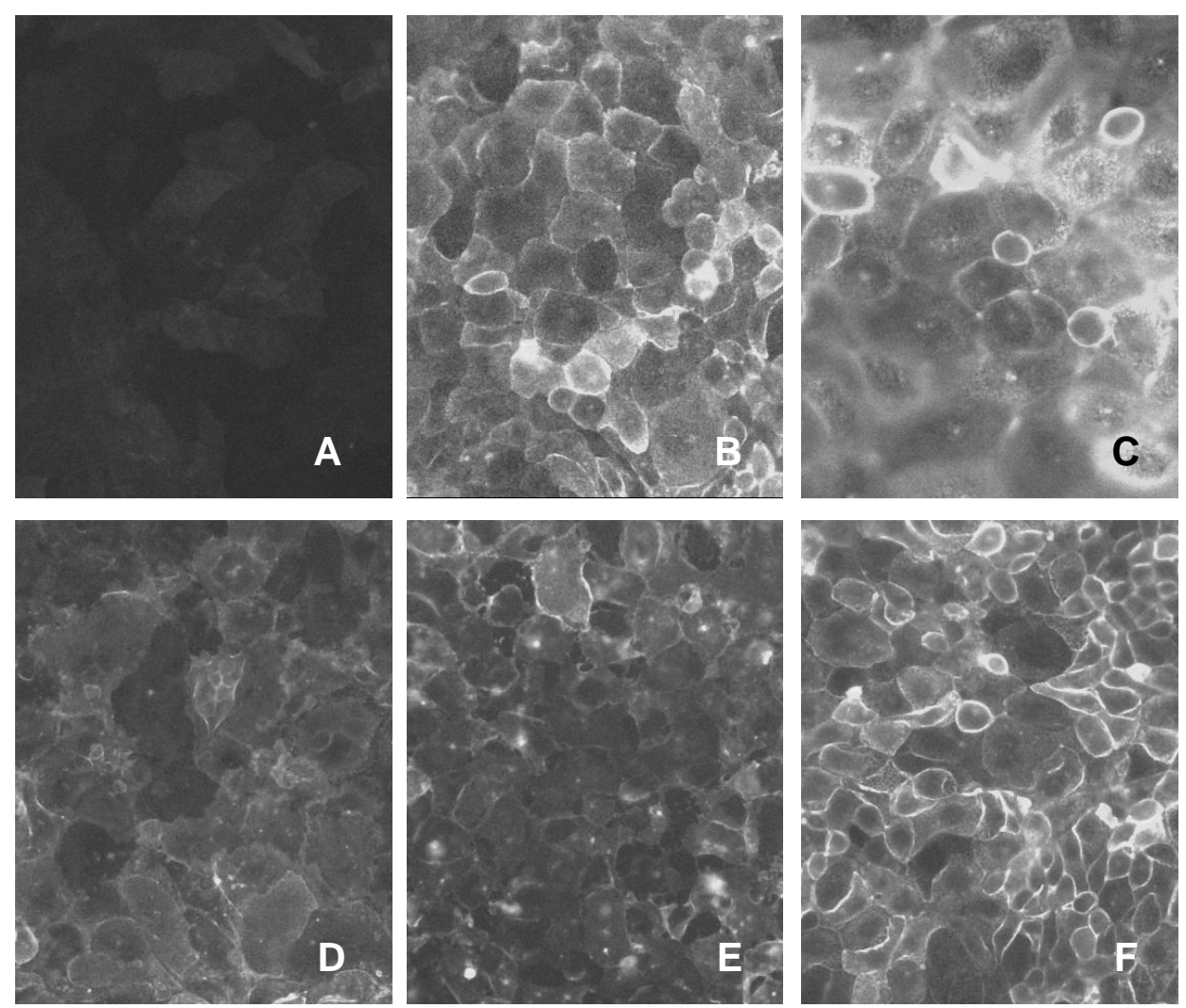

Figure 9 